\title{
USGS Science for the Nation's Changing Coasts: Shoreline Change Assessment
}

$\mathrm{T}$ he coastline of the United States features some of the most popular tourist and recreational destinations in the world and is the site of intense residential, commercial, and industrial development. The coastal zone also has extensive and pristine natural areas, with diverse ecosystems providing essential habitat and resources that support wildlife, fish, and human use. Coastal erosion is a widespread process along most open-ocean shores of the United States that affects both developed and natural coastlines. As the coast changes, there are a wide range of ways that change can affect coastal communities, habitats, and the physical characteristics of the coast - including beach erosion, shoreline retreat, land loss, and damage to infrastructure. Global climate change will likely increase the rate of coastal change. A recent study of the U.S. Mid-Atlantic coast, for example, found that it is virtually certain that sandy beaches will erode faster in the future as sea level rises because of climate change.

The U.S. Geological Survey (USGS) is responsible for conducting research on coastal change hazards, understanding the processes that cause coastal change, and developing models to predict future change. To understand and adapt to shoreline change, accurate information regarding the past and present configurations of the shoreline is essential. A comprehensive, nationally consistent analysis of shoreline movement is needed. To meet this national need, the USGS is conducting

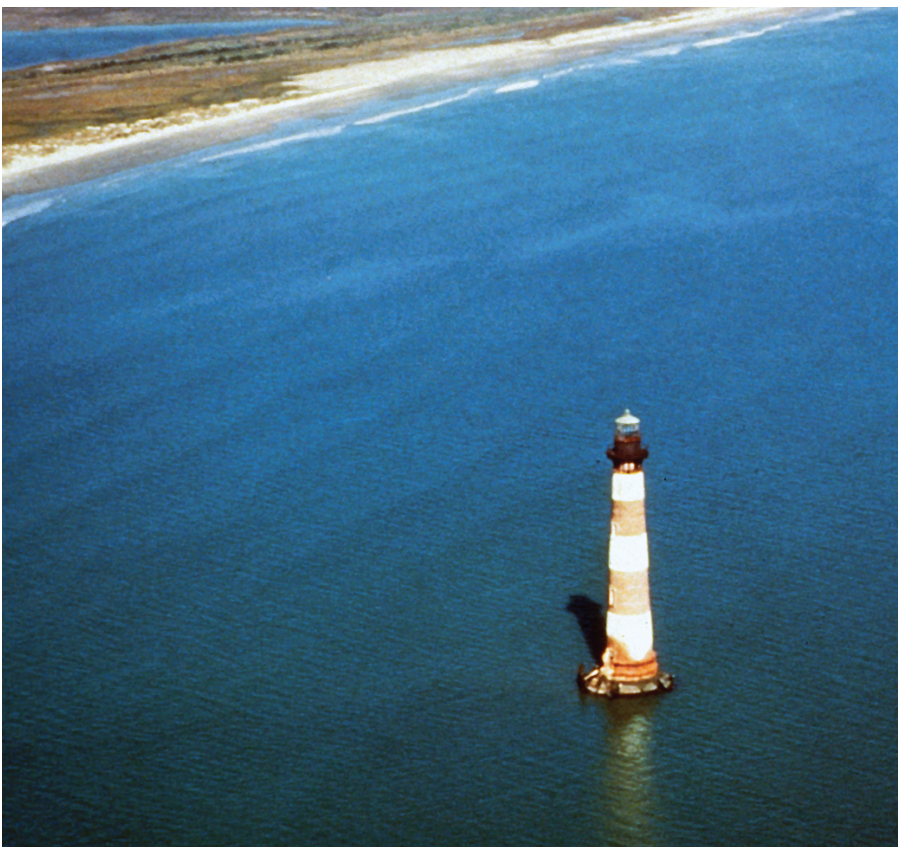

The Morris Island, South Carolina, lighthouse was built on land during 1872-1876. Long-term shoreline retreat has now left the lighthouse more than 350 meters out to sea. (Photo by Bill Neal, courtesy SEPM, Society for Sedimentary Geology.)
The USGS publishes shoreline change data for the United States through Web sites and mapping applications. Interactive maps show historical shoreline positions, rates of change, and other information, as in this example from the southwestern portion of Nantucket Island, Massachusetts.

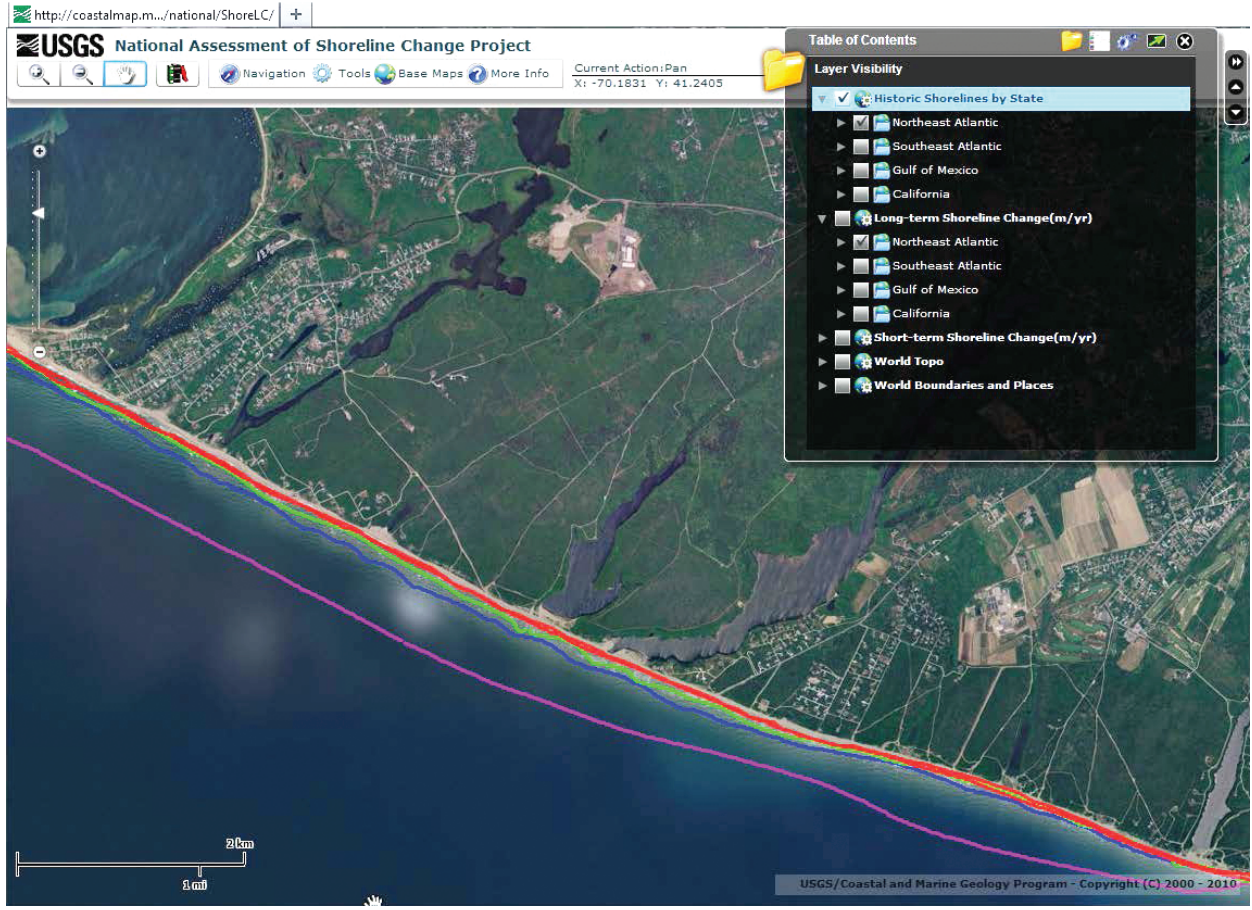


an analysis of historical shoreline changes along open-ocean coasts of the conterminous United States and parts of Alaska and Hawaii, as well as the coasts of the Great Lakes.

\section{Assessing Shoreline Change}

The principal goal of USGS long-term shoreline change assessments is to provide a regional to national view of America's changing coast. The USGS has a unique capability to integrate diverse types of data and fundamental scientific understanding to produce accurate, relevant, and timely shoreline change assessments. These assessments also support basic scientific research to understand the mechanisms of coastal
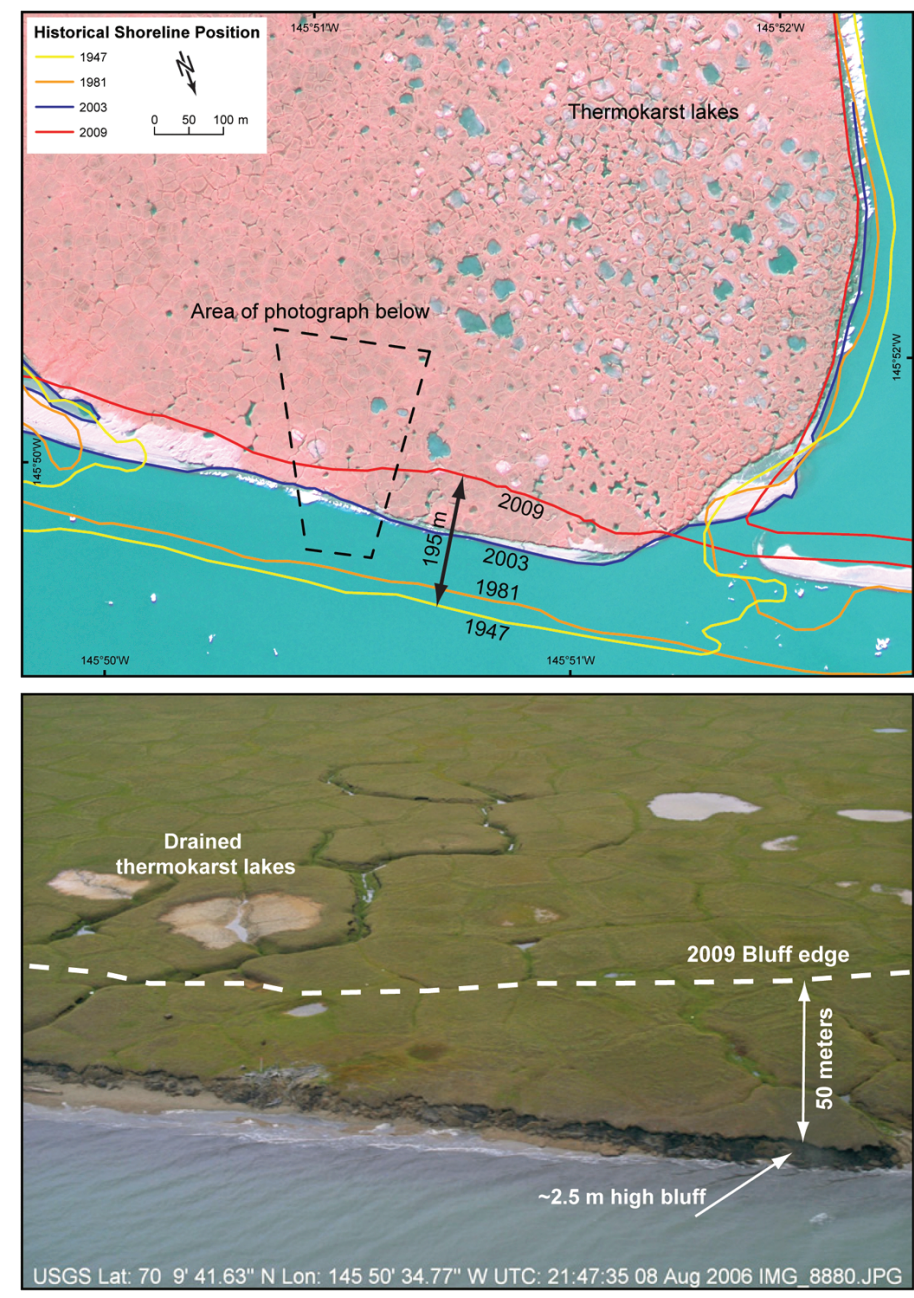

The low cliff (also termed coastal bluff) at Brownlow Point, on Alaska's northern coast, has retreated nearly 200 meters since 1947. Coastal erosion along the Arctic coast of Alaska is threatening sensitive ecosystems, energy-related infrastructure, Native Alaskan villages and traditional lifestyles, Federal Trust Species and their habitats, and large tracts of Native Alaskan, State, and Federally managed land. (Top: Map data after Gibbs, A.E., Harden, E.L., Richmond, B.M., and Erikson, L.H., 2011, Regional shoreline change and coastal erosion hazards in Arctic Alaska, in Solutions to Coastal Disasters 2011: New York, American Society of Civil Engineers, Proceedings, 16 p.-Base image is 2003 Quickbird color infrared satellite imagery, courtesy U.S. Fish and Wildlife Service. Bottom: USGS photo from Gibbs and Richmond 2009, http://pubs.usgs.gov/ds/436/.) change at time scales from storm events to millennia, and they can be used as input to other research to predict future changes in response to changing climate, including storms and sealevel rise.

A variety of data sources are used to develop long-term and robust estimates of shoreline change. Early sources of information on shoreline position include historical maps and aerial photographs. More recently, global positioning system and airborne lidar data have revolutionized the measurement and visualization of coastal topography and change. The USGS is a leader in developing standardized methods for mapping and analyzing shoreline erosion and accretion and works with Federal (for example, National Aeronautics and Space Administration, National Oceanic and Atmospheric Administration, U.S. Army Corps of Engineers), state, and academic partners to develop shoreline change data, as well as to share information and regional expertise.

\section{Understanding Shoreline Change in a Changing World}

The USGS publishes reports and maintains a national database and interactive maps of shoreline change. As more data are gathered, periodic updates are made, which provide information that can be used in multidisciplinary assessments of global change impacts.

The anticipated effects of global climate change, such as sea-level rise, increased storm intensity, and changes in river discharge and sediment transport, will likely increase the vulnerability of the coastal zone to erosion hazards. Human alteration of the coast through artificial beach nourishment or emplacement of shoreline-stabilization structures can also influence both coastal vulnerability and rates of shoreline change. These natural and human drivers of coastal change vary widely along the coast. Consistent assessment of shoreline change should enable these influences to be identified so that informed management decisions regarding coastal development and hazard mitigation can be made by a wide array of stakeholders, including Federal, state, and local agencies, nongovernmental organizations, industry, and private citizens.

\section{E. Robert Thieler and Cheryl J. Hapke rthieler@usgs.gov chapke@usgs.gov}

\section{Edited by Peter H. Stauffer}

Layout by David R. Jones

\section{For More Information}

The National Assessment of Shoreline Change Project Web site: http://coastal.er.usgs.gov/shoreline-change/.

USGS national database and interactive maps of shoreline change: http://coastalmap.marine.usgs.gov/national/shorelc/.

USGS Science for the Nation's changing coasts; shoreline change research: U.S. Geological Survey Fact Sheet 2011-3073 (http:// pubs.usgs.gov/fs/2011/3073/) 